\title{
MANAJEMEN PEMBINAAN KINERJA GURU RAUDLATUL ATHFAL (RA)DALAM BALANCED SCORECARD (BSC)
}

\author{
Fu'ad Arif Noor \\ Mahasiswa S3 - PAUDI UIN Sunan Kalijaga, NIM. 1530016040 \\ Dosen STPI Bina Insan Mulia Yogyakarta \\ Email :fuad.arif.noor@gmail.com
}

\begin{abstract}
Abstrak
Ahli manajemen menemukan suatu pendekatan penilaian kinerja perusahaan yang dapat diadopsi pada organisasi nirlaba, alat penilaian kinerja yang disebut Balanced Scorecard (BSC) merupakan metode penilaian kinerja yang komprehensif. Metode ini menilai kinerja menggunakan seperangkat ukuran kinerja terpadu yang telah disusun berdasarkan visi misi dan strategi. BSC ini mendasarkan penilaian kinerja dalam empat perspektif penting, yaitu: perspektif keuangan, perspektif pelanggan, perspektif proses internal, serta perspektif pembelajaran dan pertumbuhan.

Kinerja Guru RA adalah kesuksesannya dalam memberi upaya untuk menstimulasi, membimbing, mengasuh dan menyediakan kegiatan pembelajaran yang akan menghasilkan kemampuan dan keterampilan pada anak melalui perencanakan, pelaksanakan, dan pengevaluasi proses belajar mengajar yang intensitasnya dilandasi oleh sikap mental dan profesionalisme guru.

Esensi dari kinerja guru tidak lain merupakan kemampuan guru dalam menunjukkan kecakapan atau kompetensi yang dimilikinya dalam dunia kerja yang sebenarnya. Dunia kerja guru yang sebenarnya adalah membelajarkan anak atau anak didiknya dalam kegiatan pembelajaran di kelas, dalam kinerjanya didasari dengan kompetensi pedagogik, kompetensi kepribadian, kompetensi sosial, kompetensi professional, dan kepemimpinan.
\end{abstract}

Kata kunci: Manajemen, Pembinaan, Kinerja Guru RA, dan Balanced Scorecard

\section{A. Pendahuluan}

Pendidikan merupakan sebuah rangkaian proses pemberdayaan manusia menuju kedewasaan, baik secara akal, mental maupun moral untuk menjalankan fungsi kemanusiaan yang diemban sebagai seorang hamba dihadapan Khaliq-Nya dan sebagai pemelihara (khalifah) pada semesta (Ahmad Tafsir, 1994 : 15). Fungsi utama pendidikan adalah mempersiapkan peserta didik (generasi penerus) dengan kemampuan dan keahlian (skill) yang diperlukan agar memiliki kemampuan dan kesiapan untuk terjun ke tengah masyarakat (lingkungan). Dengan kata lain pendidikan selalu mengantarkan manusia pada perilaku dan perbuatan yang berpedoman pada syariat Allah. Sehingga pendidikan Islam bukanlah pendidikan yang hanya sekedar" transfer of knowladge" atau "transfer of training" tetapi lebih merupakan suatu sistem yang terkait secara langsung dengan Tuhan (Roehan Anwar, 1991 : 50).

Tantangan-tantangan baru itu dihadapi dengan menggunakan paradigma 
lama maka segala usaha yang dijalankan akan mendapatkan kegagalan. Begitu juga halnya dengan pendidikan apabila ingin mendapat keberhasilan, di samping harus di desain ulang (rekontruksi) supaya dapat menjawab perubahan serta tantangan saat ini (modern) baik pada sisi konsepnya, kurikulum, kualitas SDM-nya, lembagalembaga dan organisasinya namun yang paling penting adalah manajemen pendidikannya itu sendiri yang paling prioritas untuk direkontroksi agar relevan dengan perubahan zaman dan tuntutan pasar (Tilaar, $t \mathrm{t}:$ :245).

Guru adalah figur manusia sumber yang menempati posisi dan memegang peran penting dalam pendidikan. Ketika semua orang mempersoalkan masalah dunia pendidikan figur guru mesti terlibat dalam agenda pembicaraan terutama yang menyangkut persoalan pendidikan formal di sekolah. Pendidik atau guru merupakan tenaga profesional yang bertugas merencanakan dan melaksanakan proses pembelajaran, menilai hasil pembelajaran, melakukan pembimbingan dan pelatihan, serta melakukan penelitian dan pengabdian kepada masyarakat, terutama bagi pendidik pada perguruan tinggi. Hal tersebut tidak dapat disangkal kerana lembaga pendidikan formal adalah dunia kehidupan guru. sebagai besar waktu guru ada di sekolah, sisanya ada di rumah dan di masyarakat (Djamarah, 1994 : 14).

Kehadiran guru dalam proses pembelajaran di sekolah masih tetap memegang peranan yang penting. Peran tersebut belum dapat diganti dan diambil alih oleh apapun. Hal ini disebabkan karena masih banyak unsur-unsur manusiawi yang tidak dapat diganti oleh unsur lain. Guru merupakan faktor yang sangat dominan dan paling penting dalam pendidikan formal pada umumnya karena bagi siswa guru sering dijadikan tokoh teladan bahkan menjadi tokoh identifikasi diri ( Wijaya, 1994 : 9).

Guru sebagai tenaga kependidikan dalam menjalankan fungsi pendidikan dilihat sebagai totalitas yang satu sama lain secara sinergi memberikan sumbangan terhadap proses pendidikan pada tempat di mana mereka memberikan pelayanan, dengan titik tekan tenaga kependidikan di lembaga pendidikan persekolahan. Tugas tenaga kependidikan secara umum adalah memberikan pelayanan optimal kepada peserta didik khususnya dan customer pada umumnya, pada titik di mana pelayanan itu harus dilakukan.

Keberhasilan dalam upaya memberikan pelayanan optimal guru terhadap peserta didik dapat dilihat dari penguasaan materi pembelajaran yang disampaikan secara efektif dan kehadirannya diterima oleh anak didik secara ikhlas. Dia juga mampu menjadi manajer belajar yang baik, sekaligus terus belajar melalui proses pembelajaran yang dilakukannya (learning from teaching processes), bahkan belajar dari peserta didik.

Guru dalam mengajar dikatakan berkualitas apabila seorang guru dapat menampilkan kelakuan yang baik dalam usaha mengajarnya. Kelakuan guru tersebut diharapkan mencerminkan kemampuan guru dalam mengelola proses pembelajaran yang berkualitas, meliputi: kemampuan dalam mempersiapkan pengajaran, kemampuan dalam melaksanakan pengajaran dan kemam-puan mengevaluasi atau penilaian pengajaran (Suryo Subroto, $1997: 20$ ).

Peraturan Pemerintah RI. No. 27/1990, tentang : Pendidikan Pra sekolah, Bab I pasal 1 ayat 2, TK adalah salah satu bentuk pendidikan pra sekolah yang menyediakan program pendidikan dini bagi anak usia 4 tahun sampai memasuki pendidikan dasar.

Keputusan Menteri Pendidikan dan Kebudayaan RI. No. 0486/U/1992, tentang: TK, Bab I pasal 2 ayat 1, bahwa pendidikan TK merupakan wadah untuk membantu pertumbuhan dan perkembangan jasmani dan rohani anak didik sesuai dengan sifat-sifat alami anak. Tindaklanjut dalam Bab II pasal 4, bahwa anak didik di TK adalah anak usia $4-6$ 
tahun. Keputusan Menteri Pendidikan dan Kebudayaan RI No. 0125/U/1994, Tentang : Program kegiatan Belajar TK.

Raudlatul Athfal (disingkat RA) adalah salah satu bentuk satuan pendidikan anak pra sekolah pada jalur pendidikan formal yang menyelenggarakan program pendidikan umum dan pendidikan keagamaan Islam bagi anak berusia 4 (empat) sampai 6 (enam) tahun (Depag RI, 2005 : 4). RA merupakan jenjang pendidikan anak usia dini (yakni usia 6 tahun atau di bawahnya) dalam bentuk pendidikan formal, di bawah pengelolaan Departemen Agama, RA setara dengan taman kanak-kanak (TK), dimana kurikulumnya ditekankan pada pemberian rangsangan pendidikan untuk membantu pertumbuhan dan perkembangan jasmani dan rohani agar anak memiliki kesiapan dalam memasuki pendidikan lebih lanjut. Di Indonesia, menempuh pendidikan TK/RA tidaklah wajib.

Guru RA dalam kinerjanya masih fokus pada persiapan kehadiran, mempersiapkan yang penting hadir tanpa mempersiapkan alat bantu medianya apa saja yang akan diperagakan di depan kelas. Kesiapan guru sebatas membuat Rencana Pelaksanaan Pembelajaran Harian (RPPH) atau sejenisnya yang itu sudah umum dan sudah terdokumentasikan dalam buku kumpulan RPPH ataupun ada di dalam kurikulumnya, akan tetapi masih saja guru disibukkan dengan urusan seperti itu. Guru belum mampu menciptakan media baru setiap pertemuan yang menjadi daya tarik peserta didik, sehingga peserta didik kurang memiliki semangat baru untuk mengetahui hal-hal yang baru dengan beraneka media atau alat peraga yang baru.

Pendidikan yang berkualitas dibutuhkan guru yang berkualitas pula. Rendahnya kualitas pendidikan di Indonesia, tidak terlepas dari masalah rendahnya kualitas guru. Hal ini setidaknya dapat dilihat dari hasil uji kompetens iawal peserta sertifikasi tahun 2012 yang menunjukkan betapa rendahnya kompetensi guru di semua jenjang pendidikan. Sedihnya lagi masih ada guru yang mendapatkan nilail pada rentang nilai maksimum100 (Kompas 1 Mei 2012: 13).

Hal ini memperkuat pernyataan, bahwa secara nasional kompetensi guru di Indonesia masih rendah. Guru yang berkualitas di pengaruhi oleh banyak faktor diantaranya adalah kualitas calon guru yang masuk di Lembaga Pendidikan Tenaga Kependidikan (LPTK), proses pendidikan diLPTK, dan manajemen guru yang diterapkan. Manajemen guru yang efektif dimulai dari seleksi yang baik, penempatan yang transparan dan akuntabel, program induksi guru pemula yang efektif, imbalan yang memadai, dan pengembangan karier guru secara berkelanjutan.

Tanpa mengurangi keberadaan kurikulum serta lingkungan sosial budaya, guru merupakan faktor kunci keberhasilan dalam upaya meningkatkan dan memelihara kualitas pendidikan. Sebaik apapun program yang dibuat kalau kualitas gurunya tidak mendapat perhatian yang cukup, maka akhirnya hanya menjadi rutinitas, sedangkan kualitas tidak akan pernah tercapai kalau kualitas Sumber Daya Manusia tidak mendapat perhatian yang serius, maka bangsa Indonesia akan ketinggalan oleh bangsa-bangsa lain yang sudah menyadari akan pentingnya kualitas Sumber Daya Manusia. Tenaga kependidikan merupakan unsur terpenting dalam system pendidikan nasional yang diadakan dan dikembangkan untuk menyelenggarakan pengajaran, pembimbingan dan pelatihan bagi para pendidik. Diantara tenaga kependidikan ini adalah para pendidik/guru yang merupakan unsur utama.

Para ahli manajemen menemukan suatu pendekatan penilaiankinerja perusahaan yang dapat diadopsi pada organisasi nirlaba, alat penilaian kinerja yang disebut Balanced Scorecard (BSC) merupakan metode penilaian kinerja yang komprehensif. Metode ini menilai kinerja menggunakan seperangkat ukuran kinerja terpadu yang telah disusun berdasarkan 
visi misi dan strategi. BSC mendasarkan penilaian kinerja dalam empat perspektif penting, yaitu : perspektif keuangan, perspektif pelanggan, perspektif proses internal, serta perspektif pembelajaran dan pertumbuhan. Pada hakekatnya sebuah lembaga pendidikan mempunyai keempat perspektif tersebut, sehingga dengan menggunakan konsep BSC penilaian kinerja lembaga pendidikan cenderung dapat dilakukan.

Penilaian kinerja pada sekolah perlu dilakukan sebagai sarana evaluasi atas semua keputusan-keputusan strategik yang telah dilaksanakan. Keputusan strategik menjadi lan gkah dalam mencapai tujuan strategik yang ditetapkan oleh tingkat pusat. Penilaian itu diarahkan untuk menemukan lagging dan leading indicator pada tujuan-tujuan strategik, agar sekolah dapat menyimpulkan keberhasilan kinerja sebagai pendorong perubahan dan perbaikan berkelanjutan.

Penilaian pada institusi sekolah perlu dilakukan mengingat semakin meningkatnya tuntutan pada guru, karyawan dan siswa untuk semakin berkualitas. Tuntutan kepada guru dan karyawan untuk semakin profesional dan mempunyai semangat kerja yang tinggi. Terlebih pada gurunya yang bertanggungjawab mencetak kader penggerak generasi penerus bangsa 30 (tiga puluh) sampai 50 (lima puluh) tahun ke depan, dimulai dari penanaman nilainilai terbaik sejak usia dini kepada peserta didik khususnya pada Raudlatul Athfal (RA) yang mereka akan mengalami hidup pada zamannya kelak menjadi pemimpin bangsa untuk menghadapi tantangan yang sesuai dengan kehidupan mereka.

Karena itu untuk mewujudkannya, dibutuhkan suatu pengukuran kinerja untuk mengetahui sejauh mana kualitas guru RA itu kompeten dan profesional dapat bersumber dari pendekatan Balanced Scorecard (BSC) yang merupakan salah satu kerangka kerja komprehensif sebagai model pengukuran kinerja yang terpadu, tersusun dalam empat perspektif, yaitu finansial, pelanggan, proses internal, serta pembelajaran dan pertumbuhan. Berikut penulis uraikan perihal: Pengertian Pembinaan, Fungsi Pembinaan, Karakteristik Pembinaan, Guru Raudlatul Athfal (RA), Kinerja Guru RA, dan diakhiri bahasan Balanced Scorecard (BSC).

\section{B. Pembahasan}

\section{Pengertian Pembinaan}

Pembinaan berasal dari kata "bina" yang mendapatkan awalan pe- dan akhiran -an, yang berarti bangun/bangunan. Dalam kamus besar Bahasa Indonesia pembinaan berarti membina, memperbaharui, atau proses, perbuatan, cara membina, usaha, tindakan, dan kegiatan yang dilakukan secara berdaya guna dan berhasil guna untuk memperoleh hasil yang lebih baik. Secara umum pembinaan diartikan sebagai usaha untuk memberi pengarahan dan bimbingan guna mencapai suatu tujuan tertentu. Pembinaan merupakan hal umum yang dipergunakan untuk meningkatkan pengetahuan, sikap, kecakapan di bidang pendidikan, ekonomi, social, kemasyarakatan dan lainnya.

Pembinaan menekankan pada pendekatan praktis, pengembangan sikap, kemampuan dan kecakapan. Berkenaan dengan hal tersebut sesuai dengan Poerwadarminta bahwa : Pembinaan adalah usaha yang dilakukan secara sadar, terencana, teratur, dan terarah untuk meningkatkan pengetahuan, sikap dan ketrampilan subjek dengan tindakan pengarahan dan pengawasan untuk mencapai tujuan. Hal serupa diungkapkan oleh A. Maqun Hardjana, Pembinaan adalah suatu proses pembelajaran dengan melepaskan hal-hal yang sudah dimilikinya, yang bertujuan untuk membantu dan mengembangkan kecakapan dan pengetahuan yang sudah ada serta mendapatkan kecakapan dan pengetahuan untuk mencapai tujuan hidup, dan kerja yang sudah dijalani secara efektif dan efisien (A. Maqun Hardjana, 1989 : 12). 
Pembinaan merupakan totalitas kegiatan yang meliputi perencanaan, pengaturan dan penggunaan pegawai sehingga menjadi pegawai yang mampu mengemban tugas menurut bidangnya masing-masing, supaya dapat mencapai prestasi kerja yang efektif dan efisien. Pembinaan juga dapat diartikan sebagai suatu tindakan, proses, hasil atau pernyataan lebih baik. Dalam Buku Pembinaan Militer Departemen HANKAM disebutkan, bahwa :

"Pembinaan adalah suatu proses penggunaan manusia, alat peralatan, uang, waktu, metode dan sistem yang didasarkan pada prinsip tertentu untuk pencapaian tujuan yang telah ditentukan dengan daya dan hasil yang sebesar-besarnya"(Musanef, 1991 : 11).

Dalam hal suatu pembinaan menunjukkan adanya suatu kemajuan peningkatan, atas berbagai kemungkiinan peningkatan, unsur dari pengertian pembinaan ini merupakan suatu tindakan, proses atau pernyataan dari suatu tujuan dan pembinaan menunjukkan kepada "perbaikan" atas sesuatu istilah pembinaan hanya diperankan kepada unsur manusia, oleh karena itu pembinaan haruslah mampu menekan dan dalam hal-hal persoalan manusia. Hal ini sejalan dengan pendapat Miftah Thoha dalam bukunya yang berjudul "Pembinaan Organisasi" mendefinisikan, pengertian pembinaan bahwa :

a. Pembinaan adalah suatu tindakan, proses, atau pernyataan menjadi lebih baik.

b. Pembinaan merupakan suatu strategi yang unik dari suatu sistem pambaharuan dan perubahan (change).

c. Pembinaan merupakan suatu pernyataan yang normatif, yakni menjelaskan bagaimana perubahan dan pembaharuan yang berencana serta pelaksanaannya.

d. Pembinaan berusaha untuk mencapai efektivitas, efisiensi dalam suatu perubahan dan pembaharuan yang dilakukan tanpa mengenal berhenti (Miftah Thoha, 1997 : 16-17).

Dalam buku Tri Ubaya Sakti yang dikutip oleh Musanef dalam bukunya yang berjudul Manajemen Kepegawaian di Indonesia disebutkan bahwa, yang dimaksud dengan pengertian pembinaan adalah :

"Segala suatu tindakan yang berhubungan langsung dengan peren-canaan, penyusunan, pembangunan, pengembangan, pengarahan, peng-gunaan serta pengendalian segala sesuatu secara berdaya guna dan berhasil guna"(Musanef, 1991 : 11).

Pembinaan merupakan tugas yang terus menerus di dalam pengambilan keputusan yang berwujud suatu perintah khusus/umum dan instruksi-intruksi, dan bertindak sebagai pemimpin dalam suatu organisasi atau lembaga. Usaha-usaha pembinaan merupakan persoalan yang normatif yakni menjelaskan mengenai bagaimana perubahan dan pembaharuan dalam pembinaan.

\section{Fungsi Pembinaan}

Untuk mendapatkan hasil kerja yang baik, maka diperlukan adanya pegawaipegawai yang setia, taat, jujur, penuh dedikasi, disiplin dan sadar akan tanggung jawab yang dibebankan kepadanya sesuai dengan peraturan perundang-undangan kepegawaian yang berlaku, fungsi pembinaan diarahkan untuk :

a. Memupuk kesetiaan dan ketaatan.

b. Meningkatkan adanya rasa pengabdian rasa tanggung jawab, kesungguhan dan kegairahan bekerja dalam melaksanakan tugasnya.

c. Meningkatkan gairah dan produktivitas kerja secara optimal.

d. Mewujudkan suatu layanan organisasi dan pegawai yang bersih dan berwibawa.

e. Memperbesar kemampuan dan kehidupan pegawai melalui proses pendidikan dan latihan yang sesuai 
dengan kebutuhan dan perkembangan organisasi (wadah yang ditentukan).

\section{Karakteristik Pembinaan}

Menurut French dan Bell yang dikutip oleh Miftah Thoha dalam bukunya Pembinaan Organisasi mengidentifikasikan karakteristik pembinaan, yaitu :

a. Lebih memberikan penekanan walaupun tidak eksklusif pada proses organisasi dibandingkan dengan isi yang subtantif.

b. Memberikan penekanan pada kerja tim sebagai suatu kunci untuk mempelajari lebih efektif mengenai berbagai perilaku.

c. Memberikan penekanan pada manajemen yang kolaboratif dari budaya kerja tim.

d. Memberikan penekanan pada manajemen yang berbudaya sistem keseluruhan.

e. Mempergunakan model "action research".

f. Mempergunakan ahli-ahli perilaku sebagai agen pembaharuan atau katalisator.

g. Suatu pemikiran dari usaha-usaha perubahan yang ditujukan bagi prosesproses yang sedang berlangsung.

h. Memberikan penekanan kepada hubungan-hubungan kemanusiaan dan sosial.

Dengan memahami karakteristik diatas, membedakan setiap perubahan, pengembngan atau pembinaan yang dapat dijadikan suatu ukuran yang dapat membedakan antara pembinaan dengan usaha-usaha pembaharuan dan pembinaan lainnya.

\section{Guru Raudlatul Athfal (RA)}

Suatu konsep yang dapat dijadikan teori dalam pengertian guru, maka perlu ditinjau dari beberapa pendapat para ahli pendidikan. Meskipun mereka berbeda pendapat, tetapi mempunyai maksud yang sama. Guru adalahorang yang kerjanya mengajar (Anton Moeliono, t.th : 30).
Dalam masyarakat Jawa, guru dilacak melalui akronim gu dan $r u$. "Gu" diartikan dapat digugu (dianut) dan "ru" bisa diartikan ditiru (dijadikan teladan).

Hal senada juga diungkapkan oleh al-Ghazali sebagaimana dikutip oleh Zainuddin dkk. bahwa guru adalah "pendidik dalam artian umum yang bertugas serta bertanggung jawab atas pendidikan dan pengajaran". Jadi, guru adalah semua orang yang berusaha mempengaruhi, membiasakan, melatih, mengajar serta memberi suri tauladan dalam membentuk pribadi anak didik dalam bidang ibadah, jasmani, rohani, intelektual dan ketrampilan yang akan dipertanggung jawabkan pada orang tua murid, masyarakat serta kepadaAllah SWT.

Sedangkan pengertian guru RA dalam Kapita Selekta adalah yang menggunakan rujukan hasil Konferensi Internasional tentang pengertian guru adalah sebagai murabbi, muallim dan muaddib. Pengertian murabbi adalah guru agama haru sorang yang memiliki sifatrabbani, yaitu bijaksana, terpelajar dalam bidang pengetahuan tentang rabb. Pengertian muallim adalah seorang guru agama harus alimun (ilmuwan), yakni menguasai ilmu teoritik, memiliki kreativitas, komitmen yang sangat tinggi dalam mengembangkan ilmu serta sikap hidup yang selalu menjunjung tinggi nilai didalam kehidupan sehari-hari. Sedangkan pengertian $t a$ 'dib adalah itegrasi antara ilmu dan amal (Hadi Supeno, 1995 : 26).

Jadi, pengertian guru RA adalah guru yang mengajar pada satuan pendidikan Anak Usia Dini (PAUD) dalam jenjang formalnya Raudlatul Athfal atau Taman Kanak-kanakyang mempunyai kemampuan sebagai pendidik serta bertanggung jawab terhadap pesertadidik. Dalam hal ini, ada beberapa pendapat tentang sifat-sifat guru RA antara lain sebagai berikut:

a. Menurut Abdurrahman an-Nahlawi, sifat-sifat guru adalah : robbani dalam segala tujuan, tingkah laku dan 
polapikirnya. Maksudnya, dalam mendidik guru harus memiliki dalil sebagai pedoman terhadap materi yang bersangkutan. Guru hendaknya ikhlas dalam pekerjaannya, mempunyai sifat sabar dalam mendidik yang dapat dijadikan sebagai contoh dalam amal dan perbuatannya, bersifat jujur dalam menyampaikan apa yang diserukan kepada anak didik, selalu membekali diri dengan berbagai macam ilmu dan terus menerus mengadakan pengkajian. Guru hendaknya menguasai berbagai macam metode pelajaran dan menggunakannya dengan tepat, mampu mengadakan pengelolaan terhadap siswa serta tegas dan dapat berlaku adil. Guru hendaknya memahami jiwaanak, sehingga dapat memperlakukan siswanya sesuai dengan kemampuannya. Maksudnya, guru harus bisa memahami problem yang dihadapi murid (Abdurrahman an-Nahlawi, 1992 : 239-246), serta guru harus bersifat adil, tidak membeda-bedakan murid.

b. Menurut al-Ghazali dalam bukunya "Samsul Nizar", sifat-sifat guru adalah: Sabar dalam menanggapi pertanyaan murid, Senantiasa bersifat kasih tanpa pilih kasih (objektif), Duduk dengan sopan, tidak riya' atau pamer, Tidak takabur, kecuali terhadap orang yang zalim dengan maksud mencegah tindakannya, Bersikap tawadhu' dalam pertemuan ilmiah, Sikap dan pembicaraan hendaknya tertuju pada topik persoalan, Memiliki sifat bersahabat dengan murid-muridnya, Menyantuni dan tidak membentuk orang-orang bodoh, Membimbing dan mendidik murid yang bodoh dengan cara yang sebaik-baiknya, Berani untuk berkata tidak tahu terhadap masalah yang dipersoalkan, Menyampaikan hujjah yang benar (Samsul Nizar, 2002 :88).

c. MenurutAthiyahal-Abrasy,sifat-sifat guru adalah : Zuhud, bersih jiwa dan raganya, ikhlas dalam pekerjaan, bersifat pemaaf, kebapakan, mengerti tentang tabiat murid. Guru harus mengetahui tabiat pembawaan,adat kebiasaan, rasa dan pemikiran murid agar tidak kesasar dalam mendidik, serta menguasai materi pelajaran (MuhammadAthiyahal-Abrasy, 1993 : 139-141).

Demikian beberapa sifat guru RA yang dikemukakan oleh beberapa tokoh pendidikan Islam yang masing-masing berbeda tetapi saling melengkapi. Jadi, dapat disimpulkan bahwa seorang guru RA harus mempunyai sifat-sifat diatas, yaitu: ikhlas, sabar, tawadhu', jujur, adil, senantiasa bersifat kasih tanpa pilih kasih, tidak riya', tidak takabur, pemaaf dan dapat menguasai materi pelajaran. Oleh karena itu, apabila sifat-sifattersebut dilaksanakan dengan baik, maka proses belajar mengajardapatberjalandenganbaik.

\section{Kinerja Guru}

Setiap individu yang diberi tugas atau kepercayaan untuk bekerja pada suatu organisasi tertentu diharapkan mampu menunjukkan kinerja yang memuaskan dan memberikan kontribusi yang maksimal terhadap pencapaiantujuan organisasi tersebut. Kata "kinerja" dalam Kamus Besar Bahasa Indonesia adalah sesuatu yang dicapai; sebagai prestasi yang diperlihatkan atau kemampuan kerja (Poerwadarminta, t.th : 312). Secara konseptual kinerja diterjemahkan sebagai prestasi kerja, penampilan kerja, ketepatan kerja dan produktifitas kerja.

Scribner (1979) dalam Suyadi Prawirosentono mengemukakan bahwa kinerja atau performance berasal dari akar kata "to perform" yang mempunyai beberapa arti yang berarti: 1) melakukan, menjalankan, melaksanakan; 2) memenuhi atau menjalankan kewajiban suatu nazar; 3) menggambarkan suatu karakter dalam suatu permainan; 4) menggambarkannya dengan suara atau alat musik; 5) melaksanakan atau menyempurnakan tanggung jawab; 6) melakukan suatu 
kegiatan dalam suatu permainan; 7) memainkan pertunjukan/musik; dan 8) melakukan sesuatu yang diharapkan oleh seseorang atau mesin. Maka beliau menyimpulkan bahwa kinerja adalah hasil kerja yang dapat dicapai oleh seseorang atau kelompok orang dalam suatu lembaga, sesuai dengan wewenang dan tanggung jawab masing-masing, dalam rangka mencapai tujuan lembaga bersangkutan secara legal atau tidak melanggar hukum serta sesuai dengna moral atau etika (Suyadi Prawirosentono, $2008: 1-2$ ).

Muhammad As'ad mengungkapkan bahwa kinerja adalah kesuksesan seseorang dalam melaksanakan suatu pekerjaan. Kinerja itu berkenaan dengan apa yang dihasilkan seseorang dari tingkah laku kerjanya. Orang yang tingkat kinerjanya tinggi disebut sebagai orang yang produktif, begitu juga sebaliknya orang yang tingkat kinerjanya tidak mencapai standar dikatakan sebagai orang yang tidak produktif atau berkinerja rendah (Muhammad As'ad, 1995 ; 47). Sejalan dengan pendapatnya Malayu S.P. Hasibuan juga mendefinisikan kinerja atau prestasi kerja adalah suatu hasil kerja yang dicapai seseorang dalam melaksanakan tugas-tugas yang dibebankan kepadanya yang didasarkan atas kecakapan, pengalaman dan kesungguhan serta waktu (Malayu S.P. Hasibuan, 2003 : 94).

Pendidikan anak usia dini khususnya Raudlatul Athfal (RA) pada dasarnya adalah pendidikan yang diselenggarakan dengan tujuan untuk memfasilitasi pertumbuhan dan perkembangan anak secara menyeluruh atau menekankan pada pengembangan seluruh aspek kepribadian anak yang menyediakan berbagai kegiatan yang dapat mengembangkan berbagai aspek perkembangan yang meliputi aspek kognitif, bahasa, sosial, emosi, fisik, dan motorik (Masitoh, 2005 : 2). Oleh karena itu, kinerja guru RA adalah kesuksesan seseorang dalam memberi upaya untuk menstimulasi, membimbing, mengasuh dan menyediakan kegiatan pembelajaran yang akan menghasilkan kemampuan dan keterampilan pada anak melalui perencanakan, pelaksanakan, dan pengevaluasi proses belajar mengajar yang intensitasnya dilandasi oleh sikap mental dan profesionalisme guru.

Berdasarkan pendapat para ahli di atas dapat disimpulkan bahwa kinerja guru adalah hasil yang dicapai oleh guru dalam melaksanakan tugas-tugasnya yang dibebankan kepadanya yang didasarkan atas kecakapan, pengalaman dan kesungguhan serta waktu dengan output yang dihasilkan tercermin baik kualitas maupun kuantitasnya. Untuk melihat kinerja seseorang harus mengacu pada aktifitas orang tersebut selama melaksanakan tugas pokok yang menjadi tanggung jawabnya. Dalam kaitannya dengan kinerja guru dalam kesehariannya tercemin pada peran dan fungsinya tersebut. Maka kinerja guru dalam kegiatannya seperti merencanakan, melaksanakan, dan mengevaluasi proses belajar mengajar yang intensitasnya dilandasi oleh sikap mental dan profesionalisme guru.

Esensi dari kinerja guru tidak lain merupakan kemampuan guru dalam menunjukkan kecakapan atau kompetensi yang dimilikinya dalam dunia kerja yang sebenarnya. Dunia kerja guru yang sebenarnya adalah membelajarkan anak atau anak didiknya dalam kegiatan pembelajaran di kelas. Pembelajaran bagi anak usia dini termasuk RA di dalamnya memiliki kekhasan tersendiri. Pembelajaran di RA perlu memperhatikan prinsip belajar yang berorientasi pada perkembangan dan bermain yang menyenangkan, didasarkan pada minat dan pengalaman anak, mendorong terjadinya komunikasi baik secara individual maupun kelompok, dan bersifat fleksibel.

Selanjutnya untuk ruang lingkup kinerja guru dapat dilihat dari kompetensi guru dalam proses pembelajaran. Sebagaimana tercantum dalam UndangUndang No 14 tahun 2005 Bab IV pasal 10 tentang guru dan dosen, bahwa 
kompetensi adalah seperangkat pengetahuan, keterampilan, dan perilaku yang harus dimiliki, dihayati, dan dikuasai oleh guru atau dosen dalam melaksanakan tugas keprofesionalan. Peraturan Pemerintah No. 74 tahun 2008 Bab II Pasal 3 tentang Kompetensi dan Sertifikasi membagi kompetensi guru menjadi empat kompetensi yang terdiri dari: kompetensi pedagogik, kompetensi kepribadian, kompetensi sosial, kompetensi profesional.

\section{Balanced Scorecard (BSC)}

Konsep balanced scorecard dirancang untuk diterapkan pada organisasi profit, namun tidak menutup kemungkinan untuk diterapkan pada institusi pendidikan. Lembaga pendidikanjuga mempunyai empat aspek tipikal yang menjadi kajian esensial balanced scorecard untuk mengukur kinerja suatu organisasi. Hal tersebut dipertegas oleh Chang dan Chow (Otto H. Chang, 1991 : 395-412), yang menyatakan bahwa balanced scorecard merupakan alat potensial untuk mendukung perubahan dan perbaikan berkelanjutan di dalam dunia pendidikan.

Berkaitan denganpenilaian pada lembaga pendidikan atau sekolah pendekatan balanced scorecard mengukurhal penting pada indikator penyelenggaraan sekarang, pengendalian penyelenggaraan di masayang akan datang dan urusan pembiayaan. Karakteristik pengukuran dengan pendekatan balanced scorecard yaitu mengukur kesatuan dari misi dan strategi yang secara ekplisitdidesain untuk menyajikan dan mendorong hasil kinerja yang telah dicapai.Menurut Kaplan dan David P. Norton (Robet S. Kaplan dan David P. Norton, 2000 : 22), balanced scorecard dapat menerjemahkan strategi dan misi organisasi ke dalam suatu perangkat pengukuran kinerjayang komprehensif yang merupakan rerangka dalam melaksanakan strategi. Sedangkan menurut Chang dan Chow, jika balanced scorecard diadopsi dalam lembaga pendidikan maka keempat aspek diidentifikasi dengan mengikuti urutan sebagai berikut:

a. Aspek pelanggan (costumer/ stakeholder)

Aspek ini dimaksudkan untuk menjawab pertanyaan "how do costumer see us?". Aspek ini menunjukkan bagaimana baik sebuah institusi menjalankan kegiatan dan mencapai hasilsesuai harapan pelanggan.

b. Aspek bisnis internal (internal bisnis)Aspek ini dimaksudkan untuk menjawab pertanyaan "at what must we excel?". Komponen-komponen dalam aspek ini menfokuskan pada proses internal, dimana sebuah institusi harus mencapai hasil sesuai harapan pelanggan.

c. Aspek inovasi dan pembelajaran (innovation and learning)

Aspek ini dimaksudkan untuk menjawab pertanyaan "canwe continue to improve and create value?". Komponen aspek ini menfokuskan pada keberlanjutan agar menjamin dan meningkatkan kemampuannya untuk memuaskan para pelanggan.

d. Aspek keuangan (financial)

Aspek ini dimaksudkan untuk menjawab pertanyaan "how do we look to provider of financial resources?". Komponen ini memfokuskan bagaimana baik organisasi menerjemahkan hasil operasional kedalam kesejahteraan dalam bidang keuangan.

Berkaitan dengan keempat perspektif dalam balanced scorecard di atas, maka penilaian pada sekolah harus memperhatikan keempat perspektif tersebut secara menyeluruh dan digambarkan sebagai berikut:

a. Perspektif Pelanggan

Siswa atau peserta didik sebagai konsumen, dan sebagai investor bagi masa depannya memiliki peran yang 
menentukan keberlanjutan suatu sekolah. Sebagai konsumen siswa berhak atas mutu dan pelayanan pendidikan yang berkualitas. Sebagai investor siswa berhak mendapatkan keuntungan masa depan atas pengajaran dan pendidikan yang diperolahnya. Keberhasilan untuk mewujudkan harapan siswa marupakan indikator kaberhasilan sekolah, yaitu adanya sistem yang bekerja secara dinamis untuk menghasilkan lulusan dengan penempatan yang efektif, menjamin kualitas instruksional dan penunjang kegiatan akademikserta menjalin hubungan baik antara pihak sekolah dengan wali siswa.

b. Perspektif proses internal

Seperti halnya pada badan usaha, sekolah juga perlu mengidentifikasi proses terpenting yang dimanivestasikan pada pelayanan pendidikan sesuai harapan pelanggan. Proses terpenting itu didasarkan pada usaha sekolah untuk memberikan jaminan pada kualitas ProsesBelajar Mengajar (PBM) dan kualitas perangkat pendukung PBM. Dalam implementasinya, pelayanan yang telah didesain tersebut kemudian dilaksanakan dengan effective cost.

c. Perspektif Pembelajaran dan Pertumbuhan

Untuk mengoperasikan proses intern dalam rangka menghasilkan pelayanan yangmemiliki value bagi siswa, sekolah memerlukan personel yang produktif dan berkomitmen. Produktivitas ditentukan oleh kompetensi personel dan ketersediaan prasarana yang diperlukan untuk menjalankan proses intern. Komitmen personel ditentukan oleh kualitas lingkungan kerja yang dibangun di sekolah. Hal tersebut diwujudkan melalui komunikasi, penghargaan dan dukungan dari pihak sekolah untuk individu-individu dari jabatan tertinggi sampai dengan yang terbawah.

d. Perspektif Keuangan

Keunggulan di bidang keuangan diharapkan memberikan jaminan kesejahteraan pada sumber daya sekolah, keefektifan penggunaan dana dan kelangsungan proses pendidikan. Melalui keunggulan bidang keuangan, sebuah sekolah dapat mewujudkan tiga perspektifyang lain: pelanggan, proses intern, dan pembelajaran dan inovasi.

\section{Kesimpulan}

Uraian dan penjelasan pada kajian ini, terlebih pada hasil uraian yang ada dapat penulis simpulkan sebagai berikut:

1. Perbedaan dan variasi definisi manajemen yang diajukan oleh para tokoh, lebih disebabkan oleh sudut pa ndang dan latar keilmuan yang dimiliki oleh para tokoh. Akan tetapi berbagai definisi yang diajukan tersebut tidak keluar dari subsansi manajemen pada umumnya, yaitu usaha mengatur seluruh sumber daya untuk mencapai tujuan secara efektif dan efisien. Untuk mengetahui lebih mendalam pengertian manajemen, dibahas seputar asal-usul semantic dan makna dasar, awal penggunaan, serta perkembangan kata manajemen.

2. Pembinaan merupakan totalitas kegiatan yang meliputi perencanaan, pengaturan dan penggunaan pegawai sehingga menjadi pegawai yang mampu mengemban tugas menurut bidangnya masing-masing, supaya dapat mencapai prestasi kerja yang efektif dan efisien.Dalam hal suatu pembinaan menunjukkan adanya suatu kemajuan peningkatan, atas berbagai kemungkiinan peningkatan, unsur dari pengertian pembinaan ini merupakan suatu tindakan, proses atau pernyataan dari suatu tujuan dan pembinaan menunjukkan kepada "perbaikan" atas sesuatu istilah pembinaan hanya di 
perankan kepada unsur manusia, oleh karena itu pembinaan haruslah mampu menekan dan dalam hal-hal persoalan manusia.

3. Guru adalahorang yang kerjanya mengajar.Dalam masyarakat Jawa, guru dilacak melalui akronim $g u$ dan ru. "Gu" diartikan dapat digugu (dianut) dan "ru" bisa diartikan ditiru (dijadikan teladan). Jadi, guru adalah semua orang yang berusaha mempengaruhi, membiasakan, melatih, mengajar serta member suri tauladan dalam membentuk pribadi peserta didik dalam bidang ibadah, jasmani, rohani, intelektual dan ketrampilan yang akan di pertanggung jawabkan pada orang tua murid, masyarakat serta kepada Allah SWT. Sedangkan pengertian guru Raudlatul Athfal adalah yang menggunakan rujukan hasil Konferensi Internasional tentang pengertian guru Raudlatul Athfal adalah sebagai murabbi, muallim dan muaddib.

4. Seorang guru RA harus mempunyai sifat-sifat, yaitu: ikhlas, sabar, tawadhu', jujur, adil, senantiasa bersifat kasih tanpa pilih kasih, tidak riya', tidak takabur, pemaaf dan dapat menguasai materi pelajaran. Oleh karena itu, apabila sifat-sifat tersebut dilaksanakan dengan baik, maka proses belajar mengajar dapat berjalan dengan baik.

5. Manajemen kinerja dalam hal ini disebut Balanced Scorecard (BSC) adalah suatu cara meningkatkan kerja performansi secara terus menerus dalam setiap tingkatan operasi atau proses dalam setiap area fungsional dari suatu organisasi dengan menggunakan semua sumberdaya manusia dan modal yang tersedia melalui pendekatan perspektif keuangan, pelanggan (stakeholder), proses internal, serta pembelajaran dan pertumbuhan.

6. Model Pembinaan guru RA yang efektif dimulai sejak perekrutan, penempatan, induksi guru baru, kesejahteraan yang baik, dan pengembangan keprofesionalan berkelanjutan.

\section{Saran}

Implementasi Undang-undang Republik Indonesia Nomor 14 Tahun 2005 tentang Guru dan Dosen, yang diperjelas dengan Peraturan Pemerintah Nomor 19 Tahun 2005 tentang Standar Nasional Pendidikan, kemudian diperkuat dengan Peraturan Menteri Pendidikan dan Kebudayaan RI Nomor 137 tahun 2014 tentang Standar Nasional Pendidikan Anak Usia Dini, danNomor 146 tahun 2014 tentang Kurikulum 2013 Pendidikan Anak Usia Dini, sekaligus dipertegas dengan Peraturan Menteri Pendidikan Nasional RI Nomor 16 Tahun 2007 Tentang Standar Kualifikasi Akademik dan Kompetensi guru. Kesemua legalitas tersebut perlu dimenej dengan pendekatan Balanced Scorecard (BSC) sehingga menghasilkan Guru Raudlaul Athfal (RA) yang sesuai dengan harapan, lebih efektif dan efisian sebagai penggerak bangsa.

\section{E. Daftar Pustaka}

Abrasy (al-), Muhammad Athiyah, DasarDasar Pokok Pendidikan Islam, terj. BustaniA. Ghanidan Djohar Bahri (Jakarta: Bulan Bintang,1993).

Amin Abdullah, "Metodologi Penelitian untuk Pengembangan Studi Islam: Perspektif Delapan Poin Sudut Pandang", Religia: Jurnal Studistudi Agama, Vol. IV, No. 1, Januari 2005.

Borg and Gall, Educational Research, An Introduction (New York and London : Logman Inc., 1983).

Candida C. Peterson, Looking Forward Through The Lifespan Developmental Psychology (Australia; Person, 2013). 
Chang. Otto H., and Chow. Chee W., "The Balanced Scorecard : A Potential tool for supporting chang and continuous improvement in accounting education", Accounting Education (Vol. 14, No. 3, August 1999).

Chang,M. C., Supporting Teacher Reformin Indonesia (Presentasi) (Jakarta: Kongres Guru Indonesia, 2010).

Colette Gray and Sean MacBlain, Learning Theories in Childhood (London: SAGE Publications Ltd, 2012).

Departemen Agama Republik Indonesia, Pedoman Pelaksanaan Kurikulum Raudlatul Athfal (Jakarta : Direktorat Jenderal Kelembagaan Agama Islam, 2005).

Djamarah, S.B. , Prestasi belajar dan Kompetensi Guru (Surabaya: Usaha Nasional, 1994).

Hardjana. A. Maqun, Komunikasi Interpersonal (Yogyakarta : Kanisius, 1989).

Kaplan. Robet S., dan Norton. David P., Balanced Scorecard: Menetapkan startegi menjadi aksi (Jakarta : Erlangga, 2000).

Kaplan. Robet S., dan Norton. David P., The balanced scorecard: translating strategy into action (Boston, Massachusetts : Harvard Business School Press, 1996).

Kompas.1Mei2012, "Peningkatan Kualitas Guru Butuh Jawaban".Malayu S. P. Hasibuan, Manajemen Sumber Daya Manusia (Jakarta: Bumi Aksara, 2003).

Masitoh, dkk.,Pendekatan Belajar Aktif di Taman Kanak-Kanak, (Jakarta: Depdiknas Ditjet Dikti Pembinaan Pendidikan Tenaga Kependidikan dan ketenagaan Perguruan Tinggi, 2005).

Melvin L. Silberman, Active Learning: 101 Strategies to Teach Any Subject (Boston: Allyn and Bacon, 1996) Penerjemah Raisul Muttaqien; editor
Ni'mal Fata, Active Learning: 101 Cara belajar Siswa Aktif (Bandung: Nuansa Cendekia, 2014).

Michael J. Seth, Educational Fever; Society, Politics, and the Pursuits of Schooling in South Korea (Korea: University of Hawai'I Press, 2002).

Moeliono.

D.Anton,KamusBesarBahasaIndones ia(Jakarta:BalaiPustaka,t.th.).

Moleong. Lexy J., Metodologi Penelitian Kualitatif (Bandung : Remaja Rosdakarya, 2009).

Muhammad As'ad, Psikologi Industri. Edisi keempat (Yogyakarta: Liberty, 1995).

Munir. Abdul, Seni Mengelola Lembaga Pendidikan Islam (Ciputat: Arta Karya Indonesia, 2010).

Musanef, Manajemen Kepegawaian di Indonesia (Jakarta: Haji Masagung, 1991).

Nahlawi (al-), Abdurrahman, PrinsipPrinsip dan Metode Pendidikan Islam dalam Keluarga,di Sekolah dan di Masyarakat (Bandung: Diponegoro, 1992).

Nizar. Samsul, Filsafat Pendidikan Islam; Pendekatan Historis,Teoritis dan Praktis (Jakarta: Ciputat Press,2002).

Poerwadarminta, Kamus Besar Bahasa Indonesia (Jakarta : Balai Pustaka, 2006).

Rohman. A., Politik Ideologi Pendidikan (Yogyakarta: Laksbang Mediatama, 2009).

Samana. A., Profesionalisme Keguruan (Yogyakarta: Kanesius, 1994).

Soedijarto." Rekrutmen, Pendidikan, dan Penempatan, serta Pembinaan Guru untuk Menunjang Pendidikan yang Relevan dan Bermudu", Pendidikan Untuk Masyarakat Indonesia Baru: 70 Tahun Prof. Dr. H.A.R. Tilaar, MSc.Ed. (Jakarta: Grasindo, 2002).

Subroto. B. Surya, Proses Belajar Mengajar di Sekolah (Jakarta: Rineka Cipta, 1997). 
Sugiyono, Metode Penelitian Kuantitatif, Kualitatif, dan $R$ \& $D$ (Bandung : Alfa Beta, 2010).

Supeno. Hadi, Potret Guru (Jakarta: Pustaka Sinar Harapan,1995).

Suyadi Prawirosentono, Manajemen Sumber Daya Manusia Kebijakan Kinerja Karyawan Kiat Membangun Organisasi Kompetitif Era Perdagangan Bebas Dunia. Edisi kedua. Yogyakarta: BPFE, 2008).

Thoha. Miftah, Pembinaan Organisasi (Jakarta: Mutiara Ilmu, 1997).

Thoha. Chabib, Kapita Selekta Pendidikan Islam(Yogyakarta:

PustakaPelajar,1996)

Tilaar. H. A. R., Beberapa Agenda Reformasi Pendidikan Nasional Dalam Perspektif Abad21 (Magelang: IndonesiaTera, 1999).
Tim Penulis, Pedoman Penulisan Disertasi Pascasarjana UIN Sunan Kalijaga Yogyakarta 2015 (Keputusan Rektor UIN Sunan Kalijaga Yogyakarta, Nomor 137.4 Tahun 2015).

Undang-undang Republik Indonesia No. 14 Tahun 2005 tentang Guru dan Dosen.

Undang-undang Republik Indonesia No. 20 tahun 2003 tentang Sistem Pendidikan Nasional (Sisdiknas).

Usman. Moh. Uzer, Menjadi Guru Profesional (Bandung: Remaja Rosda Karya, 1998).

Wijaya, C. Dan Rusyan A.T, Kemampuan Dasar Guru dalam Proses Belajar Mengajar (Bandung: Remaja Rosdakarya, 1994).

Yamin. Martinis, Profesionalisasi Guru dan Implementasi KTSP (Jakarta: Ganung Persada Press, 2007).

Zainuddin,dkk., Seluk Beluk Pendidikan al-Ghazali (Jakarta: Bumi Aksara, 1991). 